\title{
UJI AKTIVITAS ANALGETIK EKSTRAK ETANOL DAUN KEMBANG SEPATU (Hibiscus rosa-sinensis L) PADA MENCIT JANTAN PUTIH (Mus musculus) YANG DIINDUKSI ASAM ASETAT
}

\author{
Andi Juaella Yustisi, Tanti Rahmawati \\ Program Studi D-III Farmasi STIKes Mega Rezky Makassar
}

\begin{abstract}
ABSTRAK
Daun kembang sepatu (Hibiscus rosa-sinensis L.) mengandung flavonoid yang berpotensi untuk mengurangi rasa nyeri dengan menghambat kerja enzim siklooksigenase. Penelitian ini bertujuan untuk mengetahui aktivitas analgetik ekstrak daun kembang sepatu (Hibiscus rosa-sinensis L.) pada mencit jantan putih (Mus musculus) yang diinduksi asam asetat. Dalam penelitian ini menggunakan metode rangsangan kimia (geliat). Lima belas ekor mencit dibagi menjadi 5 kelompok perlakuan yaitu kelompok I diberi $\mathrm{Na}$. CMC sebagai kontrol negatif, kelompok II diberi ibuprofen $400 \mathrm{mg}$ sebagai kontrol positif, kelompok III, IV, dan V diberi perlakuan ekstrak etanol daun kembang sepatu (Hibiscus rosa-sinensis L.) dengan dosis $50 \mathrm{mg} / \mathrm{kgBB}, 100 \mathrm{mg} / \mathrm{kgBB}$, dan $200 \mathrm{mg} / \mathrm{kgBB}$. Masing-masing kelompok diberi perlakuan secara peroral 30 menit kemudian mencit diinduksi asam asetat $1 \%$ secara intraperitonial. Selanjutnya diamati dan dihitung jumlah geliat setiap 5 menit selama 1 jam. Hasil penelitian menunjukkan bahwa ekstrak etanol daun kembang sepatu (Hibiscus rosa-sinensis L.) pada dosis $200 \mathrm{mg} / \mathrm{kgBB}$ dengan persentase $78,27 \%$ memiliki efek analgetik.
\end{abstract}

Kata kunci : Aktivitas analgetik, Daun kembang sepatu, Geliat

\section{ABSTRACT}

Hibiscus leaves (Hibiscus rosa-sinensis L.) contains flavanoid which making pain reduce with hamper the cyclooxygenase enzyme. This research aimed to know the the activity test of hibiscus leaves(Hibiscus rosa-sinensis L.) ethanol extract to the white male mice (mus musculus) that inducted by acetate acid. This research used chemical stimulation (geliat method). There were 15 mice that divided to be 5 treatment groups namely group 1 given Na.CMC as negative control, group 2 given ibuprofen $400 \mathrm{mg}$ as positive control, group III, IV and V given hibiscus leaves(Hibiscus rosasinensis L.) ethanol extract with dose $50 \mathrm{mg} / \mathrm{kgBB}, 100 \mathrm{mg} / \mathrm{kgBB}$ and $200 \mathrm{mg} / \mathrm{kgBB}$. Each group was given treatment orally during 30 minutes then mice was inducted acetate acid $1 \%$ intraperitonially the next it was observed and counted the number of geliat for every 5 minutes during 1 hour. The result of research showed that hibiscus leaves(Hibiscus rosasinensis L.) ethanol extract to the dose $200 \mathrm{mg} / \mathrm{kgBB}$ with $78.27 \%$ has analgetic effect.

Keywords : Analgetic activity, Hibiscus leaves (Hibiscus rosa-sinensis L.), Geliat

\section{PENDAHULUAN}

Indonesia sebagai negara tropis memiliki beraneka tanaman yang dapat dimanfaatkan untuk kepentingan manusia. Masyarakat Indonesia sejak zaman dahulu telah mengenal dan memanfaatkan tanaman yang mempunyai khasiat obat atau menyembuhkan penyakit. Tanaman tersebut dikenal dengan sebutan tanaman obat tradisional atau obat herbal. Salah satu tanaman yang memiliki khasiat obat adalah tanaman kembang sepatu (Hibiscus rosasinensis L) (Tamboto, 2017).

Penggunaan obat tradisional secara umum dinilai lebih aman dibandingkan obat modern, hal ini disebabkan karena obat tradisional memiliki efek samping yang relatif lebih sedikit dari pada obat modern. Efek samping obat tradisional relatif kecil jika digunakan secara tepat (Sentat, 2016).
Tanaman kembang sepatu (Hibiscus rosa-sinensis $\mathrm{L}$ ) merupakan tanaman yang dikenal sebagai tanaman hias namun banyak dimanfaatkan sebagai tanaman obat. Bunga kembang sepatu (Hibiscus rosasinensis L) berkhasiat untuk bisul, radang selaput lendir hidung, sariawan, mimisan, dan gondongan (Tamboto, 2017).

Berdasarkan hasil skrining fitokimia yang telah dilakukan oleh Tamboto (2017), ekstrak daun kembang sepatu memiliki beberapa kandungan senyawa kimia seperti alkaloid, glycoside, flavonoid, tannin, phenol dan saponin. Kandungan flavonoid yang terdapat pada daun kembang sepatu (Hibiscus rosa-sinensis L) merupakan senyawa yang dapat melindungi membran lipid dari kerusakan dan menghambat enzim cyclooxygenase1 yang merupakan jalur pertama sintesis mediator nyeri seperti prostaglandin (Afrianti, 2014). 


\section{METODE PENELITIAN}

Jenis penelitian yang dilakukan adalah metode eksperimental laboratorium dengan melakukan pengujian pada mencit jantan putih (Mus musculus), berdasarkan metode rangsang kimia yang dilakukan bertujuan untuk melihat aktivitas analgetik ekstrak daun kembang sepatu (Hibiscus rosa-sinensis L.) pada mencit (Mus musculus).

\section{ALAT DAN BAHAN}

Alat yang digunakan antara lain : Cawan porselin (Iwaki Pirex ${ }^{\circledR}$ ), Gelas kimia (Iwaki Pirex ${ }^{\circledR}$ ), Gelas ukur (Iwaki Pirex ${ }^{\circledR}$ ), Labu ukur (Iwaki Pirex ${ }^{\circledR}$ ), Kandang hewan, Kanula (New Blunt Cannula), Kaca arloji, Sendok tanduk (Pudak), Lumpang, Batang pengaduk (Pudak), Kertas saring, Mangkok maserasi, Pipet tetes (Pudak), Rotavapor, Stopwatch, Timbangan analitik (Ohaus $\left.{ }^{\circledR}\right)$, dan wadah maserasi (toples). Bahan yang digunakan yaitu : Daun Kembang Sepatu (Hibiscus rosa-sinensis L.), Mencit (Mus musculus), Asam Asetat 1\%, Na-CMC 1\%, Etanol 70\%, Ibuprofen 400 mg, dan Aluminium Foil $\left(\right.$ Klinpak $\left.^{\circledR}\right)$, Kertas perkamen.

Penelitian ini dilakukan melalui beberapa tahapan kerja sebagai berikut :

\section{SAMPEL}

Sampel daun kembang sepatu (Hibiscus rosa-sinensis L.) yang digunakan diperoleh dari kabupaten Barru Kecamatan Sumpang Binangae. Pengambilan sampel dilakukan di pagi hari pada pukul 08.00 dengan cara daun kembang sepatu (Hibiscus rosa- sinensis L.) dipetik dan dipisahkan dari batang dan daunnya.

\section{PEMILIHAN HEWAN UJI}

Hewan uji yang digunakan yaitu mencit jantan yang sehat dengan berat badan 20$30 \mathrm{~g}$. Berprilaku normal, berbulu halus, tidak mengalami penyusutan berat badan setiap harinya. Mencit yang dipakai adalah 15 ekor dimana dalam setiap perlakuan digunakan 3 ekor mencit.

\section{PEMBUATAN EKSTRAK ETANOL DAUN KEMBANG SEPATU}

\begin{abstract}
Ekstrak daun kembang sepatu (Hibiscus rosa-sinensis L.) dibuat dengan cara maserasi. daun kembang sepatu (Hibiscus rosa-sinensis L.) yang sudah dikeringkan dimasukkan ke dalam wadah gelas, kemudian di rendam dengan larutan etanol $70 \%$ sebanyak $7000 \mathrm{ml}$, ditutup dengan aluminium foil didiamkan selama 3 hari sambil sesekali diaduk. Ekstrak cair etanol $70 \%$ yang diperoleh kemudian dimasukkan kedalam mangkok maserasi lalu diuapkan dengan menggunakan rotavapor dan diperoleh ekstrak kental. Ekstrak kental yang dihasilkan disimpan dalam eksikator sebelum digunakan untuk pengujian.
\end{abstract}

\section{PEMBUATAN BAHAN UJI}

Pembuatan Suspensi Na-CMC 0,5\%

Serbuk Na-CMC ditimbang sebanyak 500mg, kemudian ditambah kan aquadest hangat sedikit demi sedikit sambil terus di gerus hingga homogen. Setelah itu semua sisa aquadest ditambahkan sampai didapatkan volume larutan $\mathrm{Na}$ CMC $100 \mathrm{ml}$.

\section{Pembuatan Suspensi Ibuprofen $\mathbf{4 0 0}$ mg}

Serbuk ibuprofen ditimbang sesuai perhitungan kemudian disuspensikan dengan larutan $\mathrm{Na}$ CMC $0,5 \%$ sedikit demi sedikit sambil di aduk lalu di ad kan hingga $100 \mathrm{ml}$.

\section{Pembuatan Larutan Asam Asetat}

Diambil asam asetat sebanyak $1 \mathrm{ml}$, kemudian diencerkan dengan aquadest dalam labu ukur hingga volume $100 \mathrm{~mL}$.

\section{Dosis Ekstrak Etanol Daun Kembang Sepatu}

Dosis ekstrak etanol daun kembang sepatu (Hibiscus rosa-sinensis L.) yang digunakan adalah $50 \mathrm{mg}, 100 \mathrm{mg}$ dan 200 $\mathrm{mg}$ diberikan secara per oral setelah diinduksi asam asetat setelah satu jam. Untuk perlakuan terhadap mencit, ekstrak etanol daun kembang sepatu (Hibiscus rosasinensis L.) dilarutkan terlebih dahulu dengan suspensi Na.CMC sebanyak $1 \mathrm{~mL}$ sebelum diberikan pada mencit. 


\section{UJI ANALGETIK}

Hewan uji dikelompokkan menjadi 5 kelompok, masing-masing kelompok terdiri dari 3 ekor hewan uji, kemudian hewan uji dipuasakan selama 18 jam. Setiap kelompok diberikan perlakuan secara per oral dengan dosis yang di tentukan.

Kelompok 1 : kontrol Negatif Na CMC 0,5\%

Kelompok II : Kontrol positif ibuprofen 400 mg

Kelompok III : Ekstrak etanol daun kembang sepatu (50 mg/kgBB)

Kelompok IV : Ekstrak etanol daun kembang sepatu (100 mg/kgBB)

Kelompok $\mathrm{V}$ : Ekstrak etanol daun kembang sepatu (200 mg/kgBB)

Setelah mencit diberi perlakuan sesuai kelompok perlakuan, 30 menit kemudian mencit diberi induktor nyeri yaitu asam asetat $1 \%$ secara intraperitonial, lalu di amati geliat mencit dalam selang waktu 5 menit selama 1 jam.

\section{Perhitungan Daya Analgetik}

Perhitungan besar kecilnya daya analgetik pada masing-masing kelompok dapat ditentukan setelah didapatkan jumlah kumulatif geliat mencit selama 1 jam dengan menghitung presentase daya analgetik masing-masing kelompok dengan rumus :

$$
\% \mathrm{DA}=100-\left(\frac{P}{K} \times 100 \%\right)
$$

Ket :

$$
\begin{array}{ll}
\mathrm{DA} & =\text { Daya Analgetik (\%) } \\
\mathrm{P} & =\text { Jumlah kumulatif kelompok perlakuan } \\
\mathrm{K} & =\text { Jumlah Kumulatif Kelompok Perlakuan }
\end{array}
$$

\section{HASIL DAN PEMBAHASAN}

Analgetik atau obat penghilang rasa nyeri adalah zat-zat yang mengurangi atau menghambat rasa nyeri tanpa menghilangkan kesadaran. Nyeri merupakan proses sensoris dan emosional yang tidak nyaman, berkaitan dengan kerusakan jaringan. keadaan psikis sangat mempengaruhi nyeri, misalnya emosi dapat menimbulkan sakit kepala, atau memperhebatnya, tetapi ada pula menghindarkan sensasi rasa nyeri. (Adikusuma, 2016).

Vol. XIV No. 2, Desember 2019

DOI: https://doi.org/10.32382/medkes.v14i2.1137
Pada penelitian ini sampel yang digunakan adalah daun kembang sepatu (Hibiscus rosa-sinensis L.). penelitian ini diawali dengan pengumpulan sampel, yaitu daun kembang sepatu sebanyak $500 \mathrm{~kg}$ yang diperoleh dari Kabupaten Barru Kecamatan Sumpang Binangae. Selanjutnya diakukan tahapan penyiapan sampel daun kembang sepatu (Hibiscus rosa-sinensis L.) dengan cara dicuci dibawah air mengalir, lalu dipotong kecil-kecil untuk mempercepat proses pengeringan, kemudian dikeringkan tanpa terkena cahaya matahari langsung.

Ekstrak etanol daun kembang sepatu (Hibiscus rosa-sinensis L.) yang diperoleh sebanyak 105 gram. Ekstrak tersebut kemudian dibuat menjadi tiga variasi konsentrasi yang berbeda yakni $50 \mathrm{mg}, 100$ $\mathrm{mg}, 200 \mathrm{mg}$ untuk dilakukan pengujian terhadap mencit. Larutan uji hasil ekstraksi daun kembang sepatu (Hibiscus rosasinensis L.) dalam berbagai konsentrasi tersebut dibuat dengan cara ditimbang ekstrak masing-masing 0,5 gram, 1 gram, dan 2 gram kemudian dilarutkan dalam 100 ml larutan $\mathrm{Na}$ CMC.

Untuk pembanding pada pengujian ini digunakan $\mathrm{Na}$ CMC 0,5\% sebagai kontrol negatif karena tidak memiliki aktivitas analgetik. Pembuatannya yaitu 0,5 gram $\mathrm{Na}$ CMC dimasukkan kedalam lumpang dan dilarukan dalam sebagian aquadest hangat, digerus dan ditambah aquadest sambil terus digerus sampai homogen. Sedangkan untuk kontrol positif digunakan tablet ibuprofen 400 $\mathrm{mg}$ yang berkhasiat sebagai analgetik, pembuatannya yaitu ditimbang 1 tablet ibuprofen dengan berat 0,65 gram kemudian digerus dan dilarukan dalam suspensi $\mathrm{Na}$ NCM $0,5 \%$ sedikit demi sedikit sambil dikocok dan di ad kan sampai $100 \mathrm{ml}$.

Pada penelitian ini, pemberian sediaan dilakukan 30 menit sebelum diberi penginduksi. Hal ini bertujuan untuk melihat kerja dari ekstrak dalam memberikan efek proteksi terhadap rasa nyeri yang akan ditimbulkan oleh penginduksi, dan untuk menyembuhkan nyeri dengan menurunkan jumlah geliatan sampai sembuh dan menyesuaikan dengan pemakaian yang biasa dipakai oleh manusia (Afrianti, 2014). 
ISSN : 1907-8153 (Print)

ISSN : 2549-0567 (Online)

Pengamatan dilakukan berdasarkan jumlah geliat yang merupakan reaksi nyeri yang diperlihatkan oleh hewan uji, pengamatan dilakukan selama 1 jam dengan selang waktu pengamatan setiap 5 menit.
Hasil pengukuran rata-rata geliat mencit (Mus musculus) pada setiap kelompok perlakuan dapat dilihat pada grafik dibawah ini.

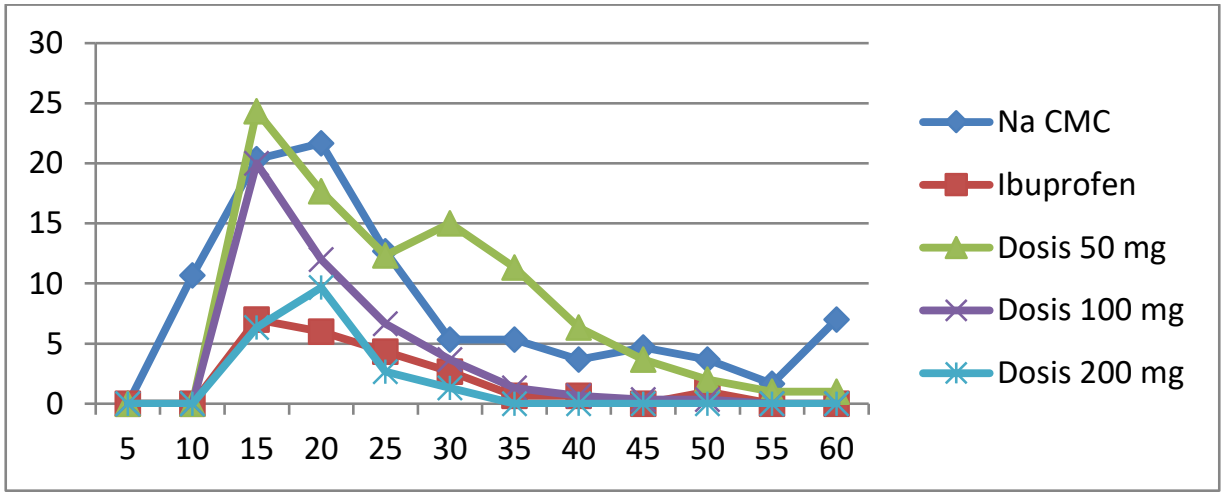

Pada grafik diatas dapat dilihat bahwa kelompok Na. CMC mengalami peningkatan geliat. Penurunan geliat yang hampir sama dengan ibuprofen yaitu dosis $200 \mathrm{mg}$.

Hasil penelitian yang didapatkan pada kemudian dilakukan uji statistik dengan uji ANOVA yang kemudian dilanjutkan uji post hoc.
Uji ANOVA ini digunakan untuk mengetahui perbedaan mean dari dua sumber variasi yaitu antar kelompok dan dalam kelompok. Dengan uji ANOVA menggunakan SPSS versi. for Windows didapatkan hasil sebagai berikut.

\section{ANOVA}

\begin{tabular}{lccccc}
\hline Perlakuan & & & & & \\
\hline & $\begin{array}{l}\text { Sum of } \\
\text { Squares }\end{array}$ & df & $\begin{array}{l}\text { Mean } \\
\text { Square }\end{array}$ & F & Sig. \\
\hline $\begin{array}{l}\text { Between } \\
\text { Groups }\end{array}$ & 1312.756 & 4 & 328.189 & 9.016 & .000 \\
\hline $\begin{array}{l}\text { Within } \\
\text { Groups }\end{array}$ & 6369.972 & 175 & 36.400 & & \\
\hline Total & 7682.728 & 179 & & & \\
\hline
\end{tabular}


Tabel 2. Persentasi daya analgetik kelompok perlakuan ekstrak etanol daun kembang sepatu (Hibiscus rosa-sinensis L.) dosis $50 \mathrm{mg} / \mathrm{kgBB}, 100 \mathrm{mg} / \mathrm{kgBB}$, dan $200 \mathrm{mg} / \mathrm{kgBB}$ dan kontrol positif (lbuprofen $400 \mathrm{mg}$ )

\begin{tabular}{lcccc}
\hline \multirow{2}{*}{ Hewan uji } & \multicolumn{5}{c}{ Jumlah kumulatif geliat } \\
\cline { 2 - 5 } & $\begin{array}{c}\text { Ibuprofen 400 } \\
\mathrm{mg} / \mathrm{kg} \mathrm{BB}\end{array}$ & \multicolumn{4}{c}{ Ekstrak etanol daun meniran } \\
\cline { 2 - 5 } Mencit I & 19 & 107 & 50 & 19 \\
\hline Mencit II & 19 & 91 & 39 & 25 \\
\hline Mencit III & 26 & 35 & 46 & 16 \\
\hline $\begin{array}{c}\text { \% Daya } \\
\begin{array}{c}\text { Analgetik } \\
\text { (DA) }\end{array}\end{array}$ & $76,87 \%$ & $15,59 \%$ & $51,09 \%$ & $78,27 \%$ \\
\hline
\end{tabular}

Dari data jumlah geliat kumulatif mencit, masing-masing kelompok perlakuan selanjutnya dibuat \% daya analgetik, hasil dapat dilihat pada tabel 2. Tabel 2 menunjukkan bahwa setiap kelompok perlakuan menunjukkan \% daya analgetik yang berbeda-beda pada tiap peringkat dosisnya. Persentase rata-rata tertinggi pada $78,27 \%$ yaitu dosis $200 \mathrm{mg} / \mathrm{kgBB}$. Persentase daya analgetik rata-rata kurang dari $50 \%$ dibanding kontrol positif pada 15,59\% yaitu dosis $50 \mathrm{mg} / \mathrm{kgBB}$. Pada dosis $100 \mathrm{mg} / \mathrm{kgBB}$ dan $200 \mathrm{mg} / \mathrm{kgBB}$ ekstrak etanol daun kembang sepatu (Hibiscus rosa-sinensis L.) positif sebagai analgetik karena \% daya analgetiknya $\geq 50 \%$.

Data yang diperoleh ditunjukkan dengan uji statistik untuk menguji sebaran datanya dengan menggunakan uji Homogenity of Variance didapatkan nilai signifikasi sebesar 0.000 selanjutnya dengan nilai signifikasi yang lebih kecil dari 0,05 $(0,000<0,05)$ maka terpenuhi syarat untuk uji ANOVA dan data menyebar secara normal atau homogen.

\section{KESIMPULAN}

Berdasarkan hasil penelitian yang telah dilakukan, ekstrak etanol daun kembang sepatu (Hibiscus rosa-sinensis L.) memiliki aktivitas sebagai analgetik teebesar pada dosis $200 \mathrm{mg} / \mathrm{kgBB}$.

\section{DAFTAR PUSTAKA}

Afrianti, Ria, Revi Yenti, Dewi Meustika. 2014. Uji Aktivitas Ekstrak Etanol Daun Pepaya (Carica papaya L.) Pada Mencit Putih Jantan yang di Induksi Asam Asetat. Sekolah Tinggi Farmasi Indonesia Yayasan Perintis. Padang.

Adikusuma Wirawan, Safwan, Dwi Rizki Ananda 2016. Aktivitas Analgeik Ekstrak Etanol Daun Melinjo (Gnetum gnemon L.) Pada Mencit Putih (Mus musculus) Jantan. Akademi Farmasi ISFI. Banjarmasin.

Sentat, Triswanto, Susiyanto. 2016. Uji Efek Analgesik Ekstrak Etanol Daun Kersen (Muntingia calabura L.) Pada Mencit Putih Jantan (Mus musculus) Dengan Induksi Nyeri Asam Asetat. Akademi Farmasi Samarinda.

Tamboto, Lesly Jessica, Heriyanis Homenta, Juliatri 2017. Uji Daya Hambat Ekstrak Daun Kembang Sepatu (Hibiscus rosasinensis L.) Terhadap Pertumbuhan Bakteri Phorphyromonas gingivalis Secara In Vitro. Pharmacon Jurnal IImiah Farmasi UNSRAT Vol.6. Manado. 